\title{
PARTY AND INCUMBENCY CUES IN VOTING: ARE THEY SUBSTITUTES? ${ }^{1}$
}

\author{
Stephen Ansolabehere \\ Department of Political Science \\ Massachusetts Institute of Technology \\ Shigeo Hirano \\ Department of Political Science \\ Columbia University \\ James M. Snyder, Jr. \\ Departments of Political Science and Economics \\ Massachusetts Institute of Technology \\ Michiko Ueda \\ Department of Political Science \\ Massachusetts Institute of Technology
}

October 11, 2005

\footnotetext{
${ }^{1}$ Stephen Ansolabehere gratefully acknowledges the support of the Carnegie Corporation under the Carnegie Scholars program. Stephen Ansolabehere and James Snyder gratefully acknowledge the financial support of National Science Foundation. Shigeo Hirano gratefully acknowledges the support of the Princeton University Center for the Study of Democratic Politics. We thank Robbie LaFleur at the Minnesota Legislative Reference Library for assistance gathering data. We also thank Tony Hill for his valuable research assistance.
} 


\begin{abstract}
A possible explanation for the rise of the incumbency advantage in U.S. elections asserts that party and incumbency are close informational substitutes. A common claim in the literature is that as the salience of partisan cues decreased, voters attached themselves to the next available piece of information - incumbency. Minnesota state legislative elections provides a unique setting for testing this idea. These elections switched from using non-partisan to partisan ballots and primaries in 1973. We find that after the switch to partisan elections, party voting increased substantially. However, contrary to expectations, the incumbency advantage increased as well. These patterns suggest that party and incumbency are not close substitutes for large numbers of voters, and that cue-substitution cannot explain the rise of the incumbency advantage.
\end{abstract}


Sometime in the middle of the twentieth century, incumbency emerged as a new force in American electoral politics. Political parties had dominated American elections for nearly a century. Although party is still the single best predictor of voter behavior, party attachments declined in the 1950s and 1960s, and incumbency emerged as a substantial additional factor in voters' reasoning and election outcomes. Aldrich and Niemi (1996) go so far as to characterize the last four decades of the century as a new electoral alignment. ${ }^{1}$

Was the rise of incumbency and the decline of party more than a historical coincidence? Some of the earliest and most comprehensive studies of the incumbency advantage argue that the declining importance of party in fact caused the incumbency advantage. In one of the seminal papers on the incumbency advantage, David Mayhew (1974, page 313) writes: "It is possible that incumbents have been profiting not from any exertions of their own but from changes in voter attitudes. A logic suggests itself. Voters dissatisfied with partisan cues could be searching for any other cues that are available in deciding how to vote. The incumbency cue is readily at hand." The behavior of modern incumbents and challengers may have contributed to the relative salience of incumbency as well. Casework, campaign advertising, and credit claiming by incumbents emphasize their performance in office and often deemphasize party (Cain, Ferejohn, and Fiorina, 1987). This view frequently appears in standard introductory texts on congress. ${ }^{2}$

In addition to the broad historical trends, some studies analyze individual-level survey data and find detailed evidence consistent with cue-substitution. Nelson (1978, page 677) summarizes her findings as follows: "As a voting cue, incumbency serves as an alternative to party identification." Cover (1977, pages 535-6) documents the increase in pro-incumbent defections from straight party voting, and even suggests that incumbency has nearly replaced

\footnotetext{
${ }^{1}$ Gelman and King (1990), Levitt and Wolfram (1997) and others show that the incumbency advantage for members of the U.S. House rose sharply during the 1960s and 1970s. Ansolabehere and Snyder (2002) find similar patterns for all nearly all statewide offices across the United States.

${ }^{2}$ Smith (1999, pages 93-4) writes: "The decline of party identification in the general electorate in recent decades has probably contributed to incumbents' advantage. As voters' psychological attachment to a major party has weakened, the proportion of the electorate voting for congressional candidates in a reflexive, partisan way has declined. This enlarged pool of 'floating' voters and weak partisans has produced more ticket splitting... incumbents also have the opportunity to exploit the weakened base of support for potential challengers from the other party. In the main, incumbents have done so." This same discussion appears in Smith, Roberts and Vander Wielen (2003). See also Davidson and Oleszek, 2002, pages 105-110.
} 
partisanship in determining congressional vote choice: "In a sense, party identification is now a meaningless voting cue for these [challenger-party] partisans in congressional elections. They are as likely to support the incumbent candidate as they are the candidate of their own party."

Some recent papers find evidence that cue-substitution may be shaped by the information environment. Goidel and Shields (1994) and Shields, Goidel and Tadlock (1995) argue that as partisan ties have weakened citizens rely more on mass media for voting cues, and since incumbents receive much more media coverage than challengers, incumbents are advantaged. Schaffner et al. (2001, page 11) investigate the following hypothesis: "By removing party identification from the ballot, less informed citizens lose their greatest information shortcut for making an educated vote... A frequently available and important voting cue is incumbency." Finally, Iyengar (2002, page 693) argues: "In the case of non-partisan judicial elections, voters may overcome their lack of information about the candidates's experience or professional/legal credentials by relying on name recognition or by taking the word of credible public figures who have endorsed particular candidates. In many cases, name recognition may provide incumbent candidates with an edge." 3

On the other hand, some findings cast doubt on the simple cue-substitution claim. Ferejohn (1977) shows that party loyalty changed little in U.S. House elections from the 1950s through the 1970s. Krehbiel and Wright (1983, page 140) argue that "dealignment accounts for little of the increase in incumbency voting." Examining U.S. Senate and state gubernatorial elections, Ansolabehere and Snyder (2002) provide mixed evidence. During the 1950s-1970s incumbency became an increasingly important predictor of the vote, while the effect of party identification fell - consistent with cue-substitution. During the 1980s, however, the importance of party identification rose, but there was no corresponding decline in the importance of incumbency. They also find little correlation between the magnitudes of the party effect and the incumbency effect across states and across types of offices.

This paper tests the cue-substitution claim by exploiting a quasi-experiment created in the shift from non-partisan to partisan elections. When party information is readily

\footnotetext{
${ }^{3}$ Other scholars have investigated the importance of other cues in low-information elections, including race, ethnicity, gender, and friends-and-neighbors (e.g., Lieske and Hillard, 1984; McDermott, 1997, 1998.)
} 
available, voters use it - in fact, it appears to be the dominant consideration for most voters. Under non-partisan elections, however, it is difficult for voters to learn the party affiliations of competing candidates. The cue-substitution claim predicts that many voters will seek other cues, including incumbency. With the shift to partisan elections, all candidates' party affiliations appear on the ballot, and voters can switch to the party cue. If cue-substitution is important, then the incumbency advantage will fall after the change, and party voting will increase, as voters rely less on incumbency status and more on party affiliation in deciding how to vote. ${ }^{4}$

Two states have used non-partisan ballots extensively for their state legislative elections - Minnesota, and Nebraska. Of these, Minnesota is an ideal case for testing the cuesubstitution claim. The timing of the change from non-partisan to partisan ballots allows us to measure how much the introduction of a strong party cue reduces the incumbency advantage. Minnesota used the non-partisan ballot and non-partisan primary for state legislative elections from 1913 to 1973. The legislature adopted the partisan ballot for its elections in 1973, well after incumbency had emerged as an important feature of U.S. elections.

We examine the long-run change in party and incumbency voting in Minnesota state senate elections from the 1950s through the 1980s. The introduction of the party ballot in the 1970s lets us examine whether voters were likely to have substituted incumbency for party in their electoral decision making. Specifically, we estimate a standard model of elections that decomposes the vote share into three components - the party normal vote, an incumbency advantage, and an idiosyncratic factor - and examine the relative strength of these three components over time, especially following the introduction of the partisan ballot. To check the robustness of our finding, we also use partisan elections for statewide offices in Minnesota and other states as reference groups against which to compare the changes in Minnesota senate elections.

We find that the introduction of party labels on the ballot and of party primaries increased party voting in Minnesota state senate elections substantially, but, contrary to expectations, the incumbency advantage increased as well. While the increase in partisanship in Minnesota

\footnotetext{
${ }^{4}$ This change can also be used to explore the importance of other cues, such as race, ethnicity, gender, geography (home-town effect, urban-rural conflict), interest group endorsements, and ballot order.
} 
legislative election runs against the national trend of the time, the increase in incumbency voting resembles trends in Minnesota partisan state elections and state elections throughout the county. The incumbency advantage in Minnesota followed the same trajectory as elsewhere in the country, despite the fact that Minnesota experienced a sudden increase in the availability of party cues. Our finding therefore suggests that incumbency and party are not close substitutes for voters, casting doubt on the cue-substitution claim that explains the rise in the incumbency advantage by the decline of party.

One other paper has studied voting behavior in Minnesota when the partisan ballot replaced the non-partisan ballot. Schaffner et al. (2001) compare two elections - the election immediately prior to the introduction of the partisan ballot and the election immediately after the change. They find that the incumbency advantage dropped 5 percentage points, from approximately 10 points to 5 points from 1972 to 1976, and the effect of party rose. Our results are quite different; we find that the incumbency advantage increased after the shift to partisan elections. There are two reasons for this discrepancy. First, they examined only two elections, which could bias their results if either of the elections was an unusual case. Indeed, as we show below, the two years that they studied were unusual in terms of the size of the incumbency advantage. Second, and related to the first point, we regard the shift in voting pattern as a long-term effect, which cannot be captured by examining such a short period of time. Ultimately, the hypothesis is about a general, long-term shift in behavior. The short-term change might reflect the temporary shock of the party ballot, or special features of the specific elections. ${ }^{5}$ A further concern is Schaffner et al.'s coding of candidates' partisan affiliation in the pre-1973 election. We discuss these issues in more detail below.

\section{Data and Methods}

We estimate how the shift from non-partisan to partisan ballots alters the effects of party and incumbency on voting. We use a well-established model of incumbency and party effects

\footnotetext{
${ }^{5}$ One of the elections used in their analysis immediately followed a redistricting. We know from the literature that the incumbency advantage following redistricting differs from the incumbency advantage in other years (e.g., Ansolabehere, Snyder and Stewart, 2000).
} 
(see Levitt and Wolfram, 1997; Ansolabehere and Snyder, 2002) to measure the extent to which incumbency and party are substitutes. We do this by estimating the shift in the incumbency and party parameters after the change from non-partisan to partisan elections.

\section{Intervention: Non-partisan and Partisan Elections}

The intervention studied in this paper is the introduction of the party ballot and primary in lieu of the non-partisan elections in Minnesota legislative elections.

The non-partisan ballot was one of several electoral reforms pushed by the progressive movement at the beginning of the twentieth century. Minnesota adopted non-partisan primaries and general election ballots for state legislative elections in 1913. Nebraska followed suit in 1934, and, in addition, created a unicameral legislature. Nebraska still has a nonpartisan, unicameral state legislature.

Apparently, the non-partisan ballot was originally passed in Minnesota because of a political miscalculation. Democrats in the legislature proposed a constitutional amendment in 1913 to make lower-level statewide elections non-partisan. As a parliamentary maneuver to kill the bill, regular Republicans attached an amendment to make state legislative elections non-partisan, thinking that some Democrats and Republican reformers would defect from the bill once their own jobs were at stake. However, many Democrats and Republican reformers embraced the entire bill as a way to distance themselves from the highly partisan debate over prohibition (Adrian, 1950; Seitz and Shaw, 1977). Primary and general elections for state legislature remained non-partisan from 1913 through 1973.

Even though elections were non-partisan, factional caucuses gave a partisan flavor to Minnesota legislative politics and elections. The legislature had organized itself into distinctive Liberal and Conservative Caucuses, especially after the merger of the Democratic and Farmer-Labor parties, and the caucuses were loosely tied to the parties in the state.

Sometime in the mid-1950s the caucuses began endorsing candidates for state legislature. This resulted in something akin to a two-party system in the state, even with non-partisan ballots and primaries. Voter guides published by the newspapers in the 1950s and 1960s reveal that almost every Conservative-endorsed candidate had a background in Republican 
politics, such as a county party chair, and every liberal-endorsed candidate had a background in Democratic politics. Also, the non-partisan primary was a run-off system where the candidates with the top vote shares in the primary were put on the ballot for the general election. It was possible for two Liberals to face each other or two Conservatives to face each other, but almost all general elections pitted a Conservative against a Liberal.

The fact that legislative caucuses and party endorsements made the elections effectively two party contests, without providing voters with the same type of information as in partisan elections, is useful for our model specification and estimation. Because of this we can refer to the candidates as Republican and Democratic, even though they were not officially nominated by the parties, and use the standard estimation techniques used for elections with two party competition.

The partisan ballot increasingly became a political issue throughout the 1960s. Republican and Conservative legislators dominated the state legislature during the non-partisan era. Following Gilbert (1962), Seitz and Shaw (1977) argue that Republicans and Conservative candidates benefitted from not having party labels on the ballot. They claim that many Minnesotans who would have voted for a Democrat were unsure of the partisan or policy positions of the competing candidates, and opted to vote for incumbents, even though they were conservatives. ${ }^{6}$

Following the 1972 elections, the Democrats controlled both the state House and state Senate. Even though they were elected on non-partisan ballots, the legislators approved the partisan ballot in 1973. Evidently, the new Democratic majority felt that this was the best way to solidify control. Importantly, if the logic of cue-substitution holds, then many legislators probably voted against their personal political interests. If cue-substitution occured, then in the non-partisan era many Minnesota state legislators won office on the basis of their incumbency advantage and personal vote. Legislators in competitive districts therefore faced more competition as a result of the introduction of the partisan ballot.

The historical context suggests that party voting was expected to increase after 1973. It is

\footnotetext{
${ }^{6}$ Several other scholars make a similar claim (e.g., Lascher, 1991). An additional argument is that Republicans and conservatives have greater access to campaign funds and other resources, and these resources are more important in low-information environments such as non-partisan elections.
} 
unclear how legislators thought this would affect their personal electoral fortunes. Observers at the time suggest that this change would lower vote margins of sitting legislators. For example, Adrian (1950, p. 387) writes that in Minnesota, "nonpartisan elections give a tremendous advantage to familiar names, particularly those of incumbents." Thus, we would expect a larger incumbency advantage in the non-partisan as compared to the partisan era.

\section{Model Specification}

We estimate a standard model of elections in which the vote is decomposed into three components - the party normal vote, an incumbency advantage, and an idiosyncratic factor (see Levitt and Wolfram, 1997; Ansolabehere and Snyder, 2002). Specifically, the Democratic share of the vote regressed on an indicator for incumbency and on a measure of the normal party vote, constructed from the vote for partisan statewide elections. The error term captures the idiosyncratic component. In the context of this model, we estimate the magnitudes of the shifts in the partisan and incumbency factors when the party ballot and primary are introduced in the 1970 s. $^{7}$

Let $V_{i t}$ be the share of the two-party vote received by the Democratic candidate running for district $i$ in year $t$. Let $I_{i t}=1$ if the Democratic candidate running for district $i$ in year $t$ is an incumbent, let $I_{i t}=-1$ if the Republican candidate running for district $i$ in year $t$ is an incumbent, and let $I_{i t}=0$ if the contest for district $i$ in year $t$ is an open-seat race. ${ }^{8}$

The normal vote, $N_{i t}$, is measured using the average Democratic vote share for various statewide offices - president, governor, U.S. Senator, secretary of state, and state auditor.

We distinguish the elections held under party ballots and primaries with those held under non-party ballots and primaries. In the regression analysis this is done with an indicator variable for those senate elections held before and after 1973. We call this dummy variable Party Ballot. Thus, let $P_{i t}=0$ if the election is held before 1973 , and let $P_{i t}=1$ if the

\footnotetext{
${ }^{7}$ Gelman and King (1990) estimate a slightly different model, which uses lagged vote to establish the expected distribution of the vote. The two models produce very similar estimates of the incumbency advantage, but it is unclear what the normal party vote is in the Gelman and King model (see Ansolabehere, Snyder, and Stewart, 2000). In particular, lagged vote is a function of lagged incumbency, so we prefer the model used here.

${ }^{8}$ In the elections immediately following each redistricting, there are a few races in which both parties' candidates are incumbents.
} 
election is held after 1973 .

The incumbency, party, and idiosyncratic factors are estimated using a simple specification where Democratic Vote in the senate election is a linear function of year effects, Incumbency, Democratic Normal Note, interactions of Incumbency and Normal Vote with Party Ballot, and idiosyncratic factors. The specifications is as follows:

$$
V_{i t}=\alpha_{t}+\alpha_{1} N_{i t}+\alpha_{2} I_{i t}+\alpha_{3} N_{i t} P_{i t}+\alpha_{4} I_{i t} P_{i t}+\epsilon_{i t}
$$

The $\alpha_{t}$ 's are year-specific fixed effects that capture partisan tides and other idiosyncratic shocks specific to a given election. The coefficient $\alpha_{3}$ captures whether there is a stronger correlation in partisan voting between the state senate and the normal vote after the change to partisan state legislative elections. The coefficient $\alpha_{4}$ captures whether there is an increase in the incumbency advantage after the change to partisan state legislative elections. If cuesubstitution exists, then we should find $\alpha_{3}>0$ and $\alpha_{4}<0$. That is, after the shift to partisan elections, we would expect a stronger relationship between the party vote share in state senate races and the normal vote, and a smaller incumbency advantage.

\section{Data and Sources}

We study Minnesota state senate elections from 1958 to 1990. Minnesota state senators are elected to four-year terms. Elections are held every year after decennial redistricting and at four year intervals thereafter. Non-partisan state senate elections were held in 1958, 1962, 1966, 1970 and 1972. Partisan senate elections were first held in 1976, then according the 4-year schedule taking into account redistricting years: 1980, 1982, 1986, and 1990.

We focus on the state senate, because many of the state lower house elections in Minnesota involved multi-seat districts during the period under study. These multi-seat races raise a variety of methodological complications. As a result, almost all studies of party voting and the incumbency advantage in U.S. elections, including the research on state legislatures, focuses on single-member districts with two competing candidates. ${ }^{9}$ Schaffner et al. (2001) examine the state senate for this reason as well. In order to stay within the well-established

\footnotetext{
${ }^{9}$ See Cox and Morgenstern (1995) for an exception.
} 
two-candidate, single-member-district framework, we focus on the state senate.

Incumbents are coded as candidates who won the previous general election or a special election held during the 4 years since the last senate general election. The cases where two incumbents run in same electoral district after redistricting are treated as districts where neither candidate has an incumbency advantage. About $75 \%$ of the races involve one incumbent against a challenger.

We calculate the normal partisan vote in any district and year, $N_{i t}$, as the average Democratic vote share in the elections for president, U.S. Senator and/or governor elections held during year $t$ when available. When the Democratic vote share for one of these offices is not available, we use the Democratic vote share for secretary of state and/or state auditor (see the notes to Table 2 for details). Also, to protect against the idiosyncracies of any one election, in all cases we use at least two statewide elections to calculate the normal partisan vote for any given year. ${ }^{10}$

Electoral data for this analysis come from three sources. The first is the Minnesota Legislative Manual. After 1974, the manual reports all statewide elections at the level of the state senate district. The second source is the precinct level election returns published by the Minnesota Secretary of State available at the Minnesota Historical Society. This source was used to measure the normal vote in the non-partisan period. We aggregated the precinct and town returns to the senate district level. The third source of data is the 1990 Record of American Democracy (ROAD) precinct level electoral data for Minnesota. ${ }^{11}$

We exclude three types of races from the analysis: (i) uncontested races, (ii) races with strong third-party candidates, and (iii) races where the two "main-party" candidates had the same partisan orientation. ${ }^{12}$ Omitting the first two types of cases is standard in the literature. The third type is unique to the non-partisan environment, however, and requires some discussion. ${ }^{13}$

Identifying candidates' party affiliations during the non-partisan era requires some detec-

\footnotetext{
${ }^{10}$ The offices and years used to calculate the normal partisan vote are listed in Table 2.

${ }^{11}$ The ROAD data are available at http://www.hmdc.harvard.edu/ROAD/.

${ }^{12}$ Out of a total of 670 races, 57 were uncontested, 6 had third-party candidates, and 24 involved two candidates of the same partisan orientation.

${ }^{13}$ It is unclear how Schaffner et al. (2001) calculate the vote share of the Democratic candidate in type-(ii) and type-(iii) races.
} 
tive work. We use two different sorts of information to identify candidates' party affiliations prior to 1973.

First, legislative caucuses and their endorsements indicate whether a candidate was oriented toward the Democratic party or the Republican party in the state. In the period used for this study, state legislators elected to office would caucus with the Liberals or Conservatives in the legislature. Although distinct from the party organizations that conducted conventions and primaries for statewide offices in the state, the legislative caucuses had strongly partisan flavor. Nearly all Democratic legislators caucused with the Liberals and nearly all Republicans caucused with the Conservatives. We assume that state legislators who caucus with the Liberals are of the "Democratic-Type" and state legislators who caucus with the Conservatives are of the "Republican-Type".

The Unofficial Legislative Directory published by the Minnesota Railroad Association contains information on caucus affiliation of state legislators for many years. The Directory does not identify the affiliation of losers in the elections. However, in all districts we know at least one candidate's partisan orientation.

Second, various information sources about the contexts of elections from 1958 to 1970 allow us to identify the partisan orientation of most candidates. Voter guides published in newspapers in Minneapolis, St. Paul, and other cities provide detailed information about the candidates, including endorsements and local committee work. Newspaper stories about the races offers additional information. And, for most of the years we found lists of party endorsements of state legislative candidates in the Minnesota Historical Society archives. ${ }^{14}$

Caucus endorsements and the archival information provides a fairly complete account of the party orientation of the candidates, and these sources consistently identify Conservative

\footnotetext{
${ }^{14}$ In a few cases there was a discrepancy in the partisan orientation of candidates across sources. Each case is examined separately. For example one case of a discrepancy is Elmer Peterson. Peterson caucused with and was endorsed by the liberals until he was kicked out of office in 1962. He ran again in 1966 to challenge the liberal incumbent who had defeated him. Peterson had a Conservative endorsement in 1966 and is thus coded as a Republican-Type. Another tough case is the 1970 election where Frank Borea ran against Edward Gearty. Both candidates received Conservative endorsement. Gearty later ran as a Democrat in 1976 so we code Gearty as the Democratic-Type orientation since he was likely to be the more left leaning of the two Conservatives. Another tough coding case in 1970 is Bill McCutcheon. In 1970 McCutcheon was endorsed by and caucused with the Conservatives, so he is coded as a Republican-Type for this election. However, in 1976 he ran as a Democrat. In 1972 McCutcheon is coded as a Democratic-Type which is consistent with the Schaffner et. al. (2001).
} 
legislators as Republicans and Liberal legislators as Democrats. Conservative endorsed candidates also served on local Republican committees, sought other offices as Republicans, or received a Republican party endorsement. The same is true of Democrats.

In all districts we are able to identify the partisan orientation of at least one of the candidates. For the cases where none of the above sources provide information about the candidates' partisan orientation, we assume that the candidate is affiliated with the party opposite the known candidates' party. This occurs in less than $15 \%$ of the districts between 1958 and 1970. ${ }^{15}$ Among the districts where both candidates' partisan orientations are known, about $10 \%$ have candidates from the same party competing in the same electoral district.

In the analysis listed below, we drop the cases where the two candidates in the general election share the same partisan orientation. This could potentially lead us to underestimate the cue-substitution effect, if most of the cue-substitution occurs when two candidates with the same partisan orientation compete against each other. However, two checks on these cases gives us confidence that this is not the case. First, the average incumbency advantage for the districts where this is true is about four percentage points, which of similar magnitude to districts where the competing candidates have different partisan orientations. ${ }^{16}$ Second, we compared the average difference between the vote share of the incumbent and the challenger in districts with two candidates of the same partisan orientation, with the average difference in these same districts in the next election when the two candidates have different partisan orientations. The difference does not appear to be any larger in the former cases.

\section{Do Voters Substitute Party for Incumbency in Minnesota State Senate Races?}

Party is a powerful piece of information in elections, and, at least since the 1960s, so

\footnotetext{
${ }^{15}$ We check the robustness of our results by running the analysis excluding those cases where we did not have some information about candidates' partisan affiliation. The substantive result remains the same.

${ }^{16}$ This is calculated by regressing the vote share of candidate $i$ in district $j$ on whether or not candidate $i$ is an incumbent or is facing an incumbent. In other words $V_{i j t}=\alpha_{t}+\alpha_{1} I_{i j t}+e_{i j t}$. Since the two candidates in each district share the same partisan-orientation, the candidates are assumed to simply split the partisan votes. 21 districts are coded as having two candidates with the same partisan orientation and are used in this analysis.
} 
too is incumbency. We test for the strength of partisan electoral cues, and the degree of substitution between party and incumbency cues, using data from Minnesota's state senate elections. In this section, we focus on the relationship between party and incumbency voting in the Minnesota state senate elections. In the next section, we consider these results in comparison with partisan statewide offices and state legislative elections in other states.

\section{Party Cues}

Even in Minnesota's non-partisan state senate elections, it appears that party provided the foundation for voting. However, the importance of party grew sharply after the introduction of the partisan primary and ballot in 1973.

To gauge the importance of party labels, and how this changed over time, we examine disaggregated voting returns at the town and precinct level. As noted above, elections for the U.S. Senate and statewide executive offices in Minnesota are partisan. Election returns for these offices are reported at the town level for rural districts and at the precinct or ward level for urban districts. Town level and precinct/ward level returns are also available for state senate races. If voters learned the party affiliations of state senate candidates even during the non-partisan era - from endorsements, newspaper stories, and so on - then there should be a strong correlation across towns and precincts/wards between the percent voting Democratic in the partisan statewide office races and the percent voting for the DemocraticType candidate in state senate races. ${ }^{17}$

Rather than classify candidates ourselves, we let the data do it for us. For each state senate race, we calculate the absolute value of the correlation coefficient between the Democratic vote share in a partisan statewide office (governor or secretary of state) and the vote share for one of the two state senate candidates. The raw correlation should be positive if we have chosen the Democratic-Type state senate candidate, and negative if we have chosen the Republican-Type candidate. ${ }^{18}$ But in either case the absolute value should be large if

\footnotetext{
${ }^{17}$ Squire and Smith (1988) find that many voters use partisan information in nonpartisan judicial elections in California.

${ }^{18}$ In the non-partisan era, almost all of the candidates whose vote shares are positively correlated with the Democratic statewide office vote shares are classified as Democratic-Types. In the partisan era, this is true of all candidates.
} 
party is a strong cue in the state senate race, and small otherwise. Let the absolute value of the correlation coefficient for district $i$ in year $t$ be $\operatorname{Corr}(S W, S S)_{i t}$. Also, for each year $t$, let $\operatorname{Corr}(S W, S S)_{t}=\sum_{i} \operatorname{Corr}(S W, S S)_{i t} / N_{t}$ be the average of these absolute correlation coefficients, where $N_{t}$ is the number of contested state senate races in year $t$.

To estimate how the impact of the party cue changed over time, we use the correlation of the Democratic vote percent between a pair of partisan statewide offices as a baseline (governor and U.S. Senator, governor and secretary of state, or U.S. Senator and secretary of state). This baseline correlation might fall, for example, if party attachments weaken over time. Let $\operatorname{Corr}(S W)_{t}$ be the relevant correlation coefficient in year $t$. For comparability with $\operatorname{Corr}(S W, S S)_{t}$, when calculating $\operatorname{Corr}(S W)_{t}$ we first compute the correlation within each senate district, then average over districts. If the party cue grew in importance after the switch from non-partisan to partisan ballots, then $\operatorname{Corr}(S W, S S)$ should rise sharply relative to $\operatorname{Corr}(S W)$.

Figure 1 plots $\operatorname{Corr}(S W, S S)$ and $\operatorname{Corr}(S W)$ in Minnesota from 1958 to 1990. We examine six elections - 1958, 1962, 1966, 1970, 1986 and 1990. See Table A.1 for a list of the statewide offices used in each year, and for the numerical estimates. ${ }^{19}$

[Figure 1]

Figure 1 also reveals the value of party cues. First, compare the degree of party voting in statewide and state legislative offices in 1958, 1962, 1966, and 1970. During these elections, candidates for statewide offices were selected through a partisan primary and elected on a partisan ballot. The average value of $\operatorname{Corr}(S W)$ for these elections is .936. This is much larger than the average for non-partisan state senate elections $(\operatorname{Corr}(S W, S S))$, which is .505 .

Second, and perhaps more important for this analysis, party cues clearly increased party voting in the state senate elections. Voting behavior in Minnesota state senate elections appears somewhat partisan even during the non-partisan years - 1958, 1962, 1966, and 1970. The value of $\operatorname{Corr}(S W, S S)$ is about .50 in each of these years, suggesting that a large

\footnotetext{
${ }^{19}$ We use 1986 and 1990 returns as sample years of the party ballot era. The precinct level data of those years are available from the ROAD project.
} 
segment of the electorate consistently voted for one party across offices even though party labels did not appear on the state senate ballots. By the 1980s, after the introduction of the party primary and ballot, the average value of $\operatorname{Corr}(S W, S S)$ had risen to .750 . This is not much different from the average baseline correlation, $\operatorname{Corr}(S W)$, which had fallen to .805 . Thus, a decade after the introduction of the party ballot and primary, the level of party voting in state senate elections was similar to that of other offices in state.

The rise in $\operatorname{Corr}(S W, S S)$ can be attributed to the stronger party cue associated with partisan elections. Having information on the ballot makes it easier for voters to identify candidates' party affiliations. Statewide elections show a high degree of party voting in the 1950s and 1960s, and levels of party voting in state senate elections converge to the rate of party voting exhibited in statewide offices.

One possible reason for the shift in voting patterns is lower roll-off, the percentage difference between the total number of votes for a particular office (state senate) and for the race at the top of the ticket (president, governor, or U.S. Senator). Studies of non-partisan judicial elections often find high roll-off rates. Lacking a strong party cue on the ballot, less informed voters might not vote for offices about which they know very little. We would expect this selection effect to strengthen the correlation between the partisan vote shares for the state senate and statewide offices even during the non-partisan period. If only the voters who are informed vote in the non-partisan elections then the voting behavior should appear very similar for the partisan and non-partisan elections.

Somewhat surprisingly, however, there was relatively little roll-off in Minnesota state senate elections before 1974. The roll-off in the non-partisan period was about $10 \%$, compared to a rate of about $6 \%$ during the partisan period. Furthermore, a majority of the state's roll-off was concentrated in the counties containing the major cities, Hennepin, Ramsey, and St. Louis. Excluding Hennepin, Ramsey, and St. Louis county districts from the analysis yields the same substantive findings.

The large number of voters who did not vote along partisan lines and who did not abstain from voting for a state senate candidate suggests that they were voting on some other cue, such as incumbency, ethnicity, hometown or gender. The next subsection examines whether 
there is evidence that voters substituted the incumbency cue for the party cue.

\section{Incumbency Advantages}

The cue-substitution claim holds that voters abandoned party labels and replaced that information with incumbency as a cue to which candidate best represented the voters' interests. This assumes that incumbency and party are substitutes in voters' minds. In the Minnesota case, the introduction of the party ballot led to a large increase in party voting. If the cue-substitution claim is right, then the ballot reforms should also have led to a long-run drop in incumbency voting in Minnesota legislative elections. By how much did incumbency voting drop from the 1960s to the 1980s?

The answer is: Not at all. Table 1 presents OLS estimates of equation (1) above. Recall that in this specification we include a dummy variable that equals 1 for all elections after 1973 and 0 before 1973. To test the party cue and cue-substitution ideas we interact the dummy variable for post 1973 with the normal vote measure and the incumbency indicator. The interactions measure the shift in the coefficient on party normal vote and the shift in the incumbency effect. If cue-substitution occurs then we expect the coefficient on party to rise (a positive interaction) and the coefficient on incumbency to fall (a negative interaction). ${ }^{20}$

[Table 1]

As in Figure 1, the regression analysis shows strong effects of party cues. The coefficient on the normal vote measures the average effect of the normal vote in the period from 1958 to 1972. The coefficient is 0.630 , with a standard error of 0.055 . This provides clear evidence of party voting before 1973. The effect, however, is not one-to-one: every additional one percent the Democrats won in statewide races translates into only .6 percentage points more in the state senate elections. After the introduction of the party ballot and primary, the effect of the normal vote rose substantially. The interaction of party Normal Vote and Party Ballot (the indicator of post 1973 elections) measures the shift in the effect of the normal

\footnotetext{
${ }^{20}$ Note that the regression also includes year-specific fixed effects (not shown in the table), so there is no need to explicitly incorporate the "main effect" - the dummy variable Party Ballot. This variable is entirely captured by the year effects.
} 
vote. The coefficient on the interaction term reveals a very significant rise in the strength of the normal vote as a predictor of election returns. This interaction is 0.358 (with a standard error of 0.083), which implies that the effect of party in the partisan period is about one, what we would expect with strong partisan voting. Adding the coefficient on the interaction to the coefficient on party yields a slope of 0.988 on the normal vote after 1973. In other words, every additional percent the Democrats won in a statewide office translated directly into an additional one percent in the state senate election.

Surprisingly, there is no evidence of substitution of party for incumbency over the longrun. The coefficient on Incumbency measures the average incumbency advantage during the elections when there was no party ballot. The coefficient is 0.053 with a standard error of 0.006. The interaction between Incumbency and Party Ballot measures the magnitude of the shift in the incumbency effect when the state legislature shifted to partisan elections. The coefficient on the interaction is 0.020 with a standard error of 0.008 . In other words, the incumbency advantage grew from 5 percentage points to 7 percentage points from the elections conducted under non-partisan ballots to the elections under partisan ballots. This runs entirely counter to the argument that party and incumbency are close substitutes in voters' minds, and that the decline of party explains the rise in incumbency advantages.

The pooled analysis is intended as an overall measure of the effects of party and incumbency over the long-run. A maintained assumption of that analysis is that the effects of party and incumbency do not trend - important overtime change is reflected in the shift parameters. We estimated the model for each election to examine short-term variations in effects and possible trends. Table 2 reports the results.

\section{[Table 2]}

The general lessons from Table 1 remain. There is clear evidence of the electoral value of the party cue, but no evidence of cue-substitution. In fact, the incumbency advantage is either unrelated to the intervention or higher. Both the party and incumbency coefficients are significantly larger over the five elections after 1973 than they were during the five elections before 1973. The party coefficients appear to shift from about 0.6 in the pre 1973 period 
to just over 1 in the post 1973 period. The incumbency effect increases from about .05 (5 percentage points) to about .07 .

Our findings differ from those of Schaffner et al. (2001) regarding cue-substitution. Table 2 reveals why. Schaffner et al. (2001) contrast party and incumbency voting in just two years - 1972 and 1976. These two years reflect the shift in partisan voting following the introduction of the party ballot and primary, but they are unusual in terms of incumbency voting. The incumbency advantage in 1972 is much larger than any election in the pre-1973 era, and the incumbency advantage in 1976 is much smaller than in any other post-1973 election.

Looking at the longer trends in party and incumbency effects, it is evident that cuesubstitution cannot explain the patterns of voting in Minnesota state senate elections. Cuesubstitution implies that as partisan voting grows, incumbency voting should fall. Instead, we find that the effects of party and incumbency are both higher in the five elections after the ballot reform than they are in the five elections before the reform.

Consistent with this, the R-squares are generally higher in the elections after the ballot reform, and the mean squared errors lower. The average adjusted R-square in the five elections before 1973 is .546, and the average in the five elections post-1973 is .756, an increase of 39 percent. Similarly, the average mean squared error for the five elections before 1973 was nearly 40 percent higher than in the five elections post-1973 (.0061 versus .0045). That is, party and incumbency together account for noticeably more of the variation in the vote after the ballot reform.

\section{Minnesota State Senate Elections in Context}

The analysis in Tables 1 and 2 might underestimate the degree to which incumbency substitutes for party. The comparison of pre-1973 and post-1973 elections or the focus on just Minnesota may mask other trends in party voting or incumbency voting in the state.

Two possibilities strike us as of immediate concern. First, partisan voting might have changed throughout the state. That is, the state might have undergone a partisan realignment in the early 1970s that led to higher degrees of party voting in all offices, not just the state senate. The patterns in Figure 1 suggest that this was clearly not the case. Statewide 
offices exhibited a high level of party voting throughout the time frame of this study. If anything party voting in statewide offices dropped off slightly in 1990. The dramatic change in party voting occurred in state legislative elections, where the party ballot was introduced.

Second, there may be more substantial changes in incumbency. For example, perhaps it was the case that incumbency was going to grow even more and the party ballot capped a trend. That is, some substitution took place but it was not observable. Does the growth of incumbency in Minnesota state legislative elections resemble what occurred elsewhere?

To gain some leverage over these questions we contrast the Minnesota senate elections with other elections in Minnesota and statewide partisan elections throughout the country, during the same period 1958-1990. The incumbency effects are estimated using a model similar to equation (1) above, but with state-times-year fixed effects to measure the normal vote. $^{21}$ As in Table 1, the effect is averaged over the periods 1958-1972 and 1974-1990.

\section{[Table 3]}

As shown in Table 3, the trends in the incumbency advantages for statewide offices are very similar to the change observed in Minnesota state senate elections. The average incumbency advantage across Minnesota statewide offices during the 1958-1972 period is 0.038 (s.e. $=0.006)$. This grew to 0.074 (s.e. $=0.014)$ for 1974-1990 period. A similar pattern exists for statewide offices across all states - the incumbency advantage grew from 0.046 (s.e. $=0.002)$ in the pre-1973 period to 0.071 (s.e. $=0.003)$ in the post-1973 period. Recall from Table 1 that the incumbency advantage in Minnesota state senate elections grew from 0.053 to 0.073 between the partisan and non-partisan periods - this tracks the nationwide trend closely and is similar to the Minnesota statewide trend as well. ${ }^{22}$ Importantly, the statewide races in these comparisons are all partisan elections, in both periods. Even though party labels are available in all of these elections, the incumbency advantage grows. And, it grows at the same rate and at roughly the same time as the incumbency effect in Minnesota's

\footnotetext{
${ }^{21}$ For statewide offices, we can use state-times-year fixed effects because multiple statewide offices are contested simultaneously in almost all states. For further details on the data and estimates see Ansolabehere and Snyder (2002).

${ }^{22}$ Incidentally, these results suggest that the rise in incumbency in Minnesota state senate elections is not purely an artifact of redistricting that favors incumbents.
} 
senate elections.

\section{Conclusion}

The introduction of the partisan primary and ballot in Minnesota legislative elections provides a good test of the claim that incumbency advantages rose because of the substitution of incumbency for party cues. In Minnesota legislative elections, clear party cues were introduced through the ballot reforms of 1973. The introduction of party primaries and ballots after 60 years of non-partisan elections produced a substantial change in partisan information available to voters for state senate elections. It did not, however, lead to a decrease in incumbency voting. Rather, the incumbency advantage in Minnesota legislative elections followed the same trajectory as other offices in Minnesota and partisan state elections throughout the country. Party is a cue, but it is not necessarily a substitute for incumbency.

Why is there no tradeoff between party and incumbency? The claim that voters substitute party for incumbency, we think, rests on an assumed accounting identity. The identity is this: The vote for any office is divided into the party normal vote and the incumbency vote. Incumbency and party provide perhaps the two most important pieces of information in elections and voting. However, these are not the only factors that voters use. Voters are also attentive to ethnicity and race, religion, personality, "friends and neighbors," campaigning, and endorsements by social and economic interest groups and other politicians. All of these other factors may cut across incumbency or party. What is missing from the above accounting is the vast array of other sorts of information about individual candidates and circumstances of elections that are not accounted for by either of these terms and which vary over time. These other, largely idiosyncratic factors are relegated to the error term in the standard regression model of the vote.

What has changed over the last 50 years, as Ansolabehere and Snyder (2002) document, is the rise of the importance of incumbency and of idiosyncratic factors in elections, along with the decline in party as a component of the vote. Just as incumbency and party in fact consist of many different components, such as casework, get-out-the vote activities, and position taking, the idiosyncratic features consist of many factors. Some of these factors 
include variation in the types of people who choose to run for office (such as ethnicity and personal political experience) and shifting coalitions within parties.

Our analysis of roll-off provides further evidence that in the absence of party, voters do not necessarily key off of incumbency. In the Minnesota senate elections in 1958, 1962, 1966, and 1970, 94 percent of people who voted in the partisan elections for governor or U.S. Senator also voted in the non-partisan state senate elections. The incumbency cue mattered relatively little in these elections, compared to the partisan senate elections in the 1970s and 1980s. Although partisan and ideological endorsements mattered, they too mattered less. Voters in the 1960s, then, most likely relied on other features of the candidates, such as ethnicity, geography, or endorsements by other leaders.

If these other factors are sufficiently important, there may be no necessary accounting identity between party and incumbency. In the period before 1973, about half of the variability in voting is due to factors other than party and incumbency. Incumbency and party together explained about $55 \%$ percent of the variance in the vote. Voters clearly keyed off of other pieces of information. After 1973, the regressions explain about $75 \%$ percent of the variation in the vote within any election. The rise in party in no way seems to have weakened incumbency; instead, the two increased in tandem.

Minnesota's experiment with non-partisan state legislative elections illustrates that party and incumbency are not close substitutes in voters' minds and behavior. The incumbency advantage in these races was not unusually high during the period of non-partisan ballots, and it did not fall sharply following the shift to partisan ballots. It simply followed the same upward trend found in other elections. 


\section{REFERENCES}

Adrian, Charles R. 1950. "The Nonpartisan Legislature in Minnesota" Ph.D. thesis, University of Minnesota.

Aldrich, John H., and Richard G. Niemi. 1996. "The Sixth American Party System: Electoral Change, 1952-1992." In Broken Contract?, edited by Stephen C. Craig. Boulder, CO: Westview Press.

Ansolabehere, Stephen, James M. Snyder, Jr., and Charles Stewart, III. 2000. "Old Voters, New Voters, and the Personal Vote: Using Redistricting to Measure the Incumbency Advantage." American Journal of Political Science 44: 17-34.

Ansolabehere, Stephen and James M. Snyder, Jr. 2002. "The Incumbency Advantage in U.S. Elections: An Analysis of State and Federal Offices, 1942-2000." Election Law Journal 1:315-338.

Cain, Bruce, John Ferejohn, and Morris P. Fiorina. 1987. The Personal Vote. Cambridge, MA: Harvard University Press.

Cover, Albert D. 1977. "One Good Term Deserves Another: The Advantage of Incumbency in Congressional Elections." American Journal of Political Science 21: 523-541.

Cox, Gary W., and Scott Morgenstern. 1995. "The Incumbency Advantage in Multimember Districts: Evidence from the U.S. States." Legislative Studies Quarterly 20: 329-349.

Davidson, Roger H., and Walter J. Oleszek. 2002. Congress and It's Members. Eighth edition. Washington DC: CQ Press.

Ferejohn, John A. 1977. "On the Decline of Competition in Congressional Elections." American Political Science Review 71: 166-176.

Gelman, Andrew, and Gary King. 1990. "Estimating Incumbency Advantage without Bias." American Journal of Political Science 34: 1142-1164.

Gilbert, Charles E. 1962. "Some Aspects of Nonpartisan Elections in Large Cities." Midwest Journal of Political Science 6: 345-362.

Goidel, Robert K. and Todd G. Shields. 1994. "The Vanishing Marginals, the Bandwagon, and the Mass-Media." Journal of Politics 56: 802-810.

Iyengar, Shanto. 2002. "The Effects of Media-Based Campaigns on Candidate and Voter Behavior: Implications for Judicial Elections." Indiana Law Review 35: 691-700.

Krehbiel, Keith, and John R. Wright. 1983. "The Incumbency Effect in Congressional Elections: A Test of Two Explanations." American Journal of Political Science 27: 140-157.

Lascher, Edward, L. Jr. 1991. "The Case of the Missing Democrats: Reexamining the "Republican Advantage" in Nonpartisan Elections." Western Political Quarterly 44: 656-675. 
Levitt, Steven D., and Catherine D. Wolfram. 1997. "Decomposing the Sources of Incumbency Advantage in the U.S. House." Legislative Studies Quarterly 22: 45-60.

Lieske, Joel and Jan William Hillard. 1984. "The Racial Factor in Urban Elections." Western Political Quarterly 37: 545-563.

Mayhew, David R. 1974. "Congressional Elections: The Case of the Vanishing Marginals." Polity 6: 295-317.

McDermott, Monika K. 1997. "Voting Cues in Low-Information Elections: Candidate Gender as a Social Information Variable in Contemporary United States Elections." American Journal of Political Science 41: 270-283.

McDermott, Monika K. 1998. "Race and Gender Cues in Low-Information Elections." Political Research Quarterly 51: 895-918.

Nelson, Candice J. 1978-79. "The Effect of Incumbency on Voting in Congressional Elections." Political Science Quarterly 93: 665-678.

Schaffner, Brian F., Matthew Streb, and Gerald Wright. 2001. "Teams Without Uniforms: The Nonpartisan Ballot in State and Local Elections." Political Research Quarterly 54:7-30.

Seitz, Steven T. and L. Earl Shaw. 1977. "Partisanship in a Non-Partisan Legislature: Minnesota." In Millard Gieske and Edward Brandt, eds., Perspectives on Minnesota Government and Politics Dubuque, IA: Kendall/Hunt.

Shields, Todd G., Robert K. Goidel and Barry Tadlock. 1995. "The Net Impact of Media Exposure on Individual Voting Decisions in U. S. Senate and House Elections." Legislative Studies Quarterly 20: 415-430.

Smith, Stephen S. 1999. The American Congress. Second edition. Boston: Houghton Mifflin.

Smith, Stephen S., Jason Roberts, and Ryan Vander Wielen. 2003. The American Congress. Third edition, online version. Houghton Mifflin.

Squire, Peverill, and Eric R.A.N. Smith. 1988. "The Effect of Partisan Information on Voters in Nonpartisan Elections." Journal of Politics 50: 169-179. 
Table 1

Pooled Estimates of the Incumbency Advantage State Senate Races, 1958-1990

Dep. Var. = Democratic Share of Two-Party Vote

\begin{tabular}{|l|c|}
\hline Incumbency & 0.053 \\
Incumbency $\times$ Party Ballot & $(0.006)$ \\
& 0.020 \\
Normal Vote & $(0.008)$ \\
& 0.630 \\
Normal Vote $\times$ Party Ballot & $(0.055)$ \\
& 0.358 \\
\hline & $(0.083)$ \\
Obs & 583 \\
MSE & 0.698 \\
\end{tabular}

Standard errors in parentheses.

Year-effects are included but not shown above. 


\begin{tabular}{|c|c|c|c|c|c|}
\hline \multicolumn{6}{|c|}{$\begin{array}{c}\text { Table } 2 \\
\text { Estimates of the Incumbency Advantage } \\
\text { State Senate Races, 1958-1990 }\end{array}$} \\
\hline & 1958 & 1962 & 1966 & 1970 & 1972 \\
\hline Incumbent & $\begin{array}{c}0.055 \\
(0.011)\end{array}$ & $\begin{array}{c}0.042 \\
(0.012)\end{array}$ & $\begin{array}{c}0.028 \\
(0.013)\end{array}$ & $\begin{array}{c}0.055 \\
(0.017)\end{array}$ & $\begin{array}{c}0.087 \\
(0.017)\end{array}$ \\
\hline Normal Vote & $\begin{array}{c}0.672 \\
(0.095)\end{array}$ & $\begin{array}{c}0.595 \\
(0.112)\end{array}$ & $\begin{array}{c}0.644 \\
(0.117)\end{array}$ & $\begin{array}{c}0.594 \\
(0.168)\end{array}$ & $\begin{array}{c}0.666 \\
(0.178)\end{array}$ \\
\hline Constant & $\begin{array}{c}0.121 \\
(0.054)\end{array}$ & $\begin{array}{c}0.177 \\
(0.060)\end{array}$ & $\begin{array}{c}0.127 \\
(0.062)\end{array}$ & $\begin{array}{c}0.173 \\
(0.099)\end{array}$ & $\begin{array}{c}0.102 \\
(0.104)\end{array}$ \\
\hline \multirow[t]{2}{*}{$\begin{array}{l}\text { Adjusted } R^{2} \\
\text { Obs }\end{array}$} & $\begin{array}{c}0.642 \\
52\end{array}$ & $\begin{array}{c}0.556 \\
55\end{array}$ & $\begin{array}{c}0.533 \\
55\end{array}$ & $\begin{array}{c}0.429 \\
56\end{array}$ & $\begin{array}{c}0.572 \\
62\end{array}$ \\
\hline & 1976 & 1980 & 1982 & 1986 & 1990 \\
\hline Incumbent & $\begin{array}{c}0.061 \\
(0.013)\end{array}$ & $\begin{array}{c}0.069 \\
(0.014)\end{array}$ & $\begin{array}{c}0.063 \\
(0.012)\end{array}$ & $\begin{array}{c}0.089 \\
(0.010)\end{array}$ & $\begin{array}{c}0.079 \\
(0.010)\end{array}$ \\
\hline Normal Vote & $\begin{array}{c}0.995 \\
(0.141)\end{array}$ & $\begin{array}{c}1.096 \\
(0.150)\end{array}$ & $\begin{array}{c}0.998 \\
(0.115)\end{array}$ & $\begin{array}{c}0.955 \\
(0.119)\end{array}$ & $\begin{array}{c}0.911 \\
(0.114)\end{array}$ \\
\hline Constant & $\begin{array}{l}-0.082 \\
(0.091)\end{array}$ & $\begin{array}{c}0.039 \\
(0.064)\end{array}$ & $\begin{array}{c}0.016 \\
(0.060)\end{array}$ & $\begin{array}{c}0.000 \\
(0.065)\end{array}$ & $\begin{array}{c}0.017 \\
(0.065)\end{array}$ \\
\hline $\begin{array}{l}\text { Adjusted } R^{2} \\
\text { Obs }\end{array}$ & $\begin{array}{c}0.714 \\
58\end{array}$ & $\begin{array}{c}0.671 \\
60\end{array}$ & $\begin{array}{c}0.775 \\
60\end{array}$ & $\begin{array}{c}0.850 \\
62\end{array}$ & $\begin{array}{c}0.773 \\
63\end{array}$ \\
\hline
\end{tabular}

Standard errors in parentheses.

Normal Vote in 1958, 1966, 1970, and 1982 measured by governor and U.S. Senator vote in the same election year.

Normal Vote in 1962 and 1986 measured by governor, secretary of state and state auditor in the same election year.

Normal Vote in 1972 measured by governor, secretary of state and state auditor in 1974.

Normal Vote in 1976 measured by president and U.S. senate vote in 1976.

Normal Vote in 1980 measured by president vote (1980) and U.S. senator and governor vote (1978).

Normal Vote in 1990 measured by secretary of state and U.S. Senator vote in the same election year. 


\begin{tabular}{|c|c|c|}
\hline \multicolumn{3}{|c|}{$\begin{array}{c}\text { Table } 3 \\
\text { Estimates of the Incumbency Advantage } \\
\text { Regression Estimates, 1958-1990 }\end{array}$} \\
\hline & 1958-1972 & 1974-1990 \\
\hline MN, Statewide & $\begin{array}{c}0.038 \\
(0.006)\end{array}$ & $\begin{array}{c}0.074 \\
(0.014)\end{array}$ \\
\hline Obs & 40 & 30 \\
\hline MN, State Senate & $\begin{array}{c}0.053 \\
(0.006)\end{array}$ & $\begin{array}{c}0.073 \\
(0.005)\end{array}$ \\
\hline Obs & 280 & 303 \\
\hline All other states, Statewide & $\begin{array}{c}0.046 \\
(0.002)\end{array}$ & $\begin{array}{c}0.071 \\
(0.003)\end{array}$ \\
\hline Obs & 1,590 & 1,429 \\
\hline
\end{tabular}

Standard errors in parentheses. 


\begin{tabular}{|c|c|c|}
\hline \multicolumn{3}{|c|}{ Table A.1 } \\
$\begin{array}{c}\text { Average } \\
\text { Ubsolute Correlation Coefficients } \\
\text { Using Precinct Level Election Data }\end{array}$ \\
\hline $\begin{array}{c}\text { Election } \\
\text { Year }\end{array}$ & $\operatorname{Corr}(S W, S S)$ & $\operatorname{Corr}(S W)$ \\
& $(1)$ & $(2)$ \\
\hline 1958 & 0.431 & 0.917 \\
1962 & 0.525 & 0.946 \\
1966 & 0.546 & 0.949 \\
1970 & 0.517 & 0.931 \\
1986 & 0.754 & 0.847 \\
1990 & 0.752 & 0.770 \\
\hline
\end{tabular}

(1) correlation between Governor and State Senate for 1958, 1962, 1966, 1970, 1986.

(1) correlation between Secretary of State and State Senate for 1990.

(2) correlation between Governor and U.S. Senate for 1958, 1966, 1970.

(2) correlation between Secretary of State and U.S. Senate for 1990.

(2) correlation between Governor and Secretary of State for 1962, 1986. 
Figure 1:

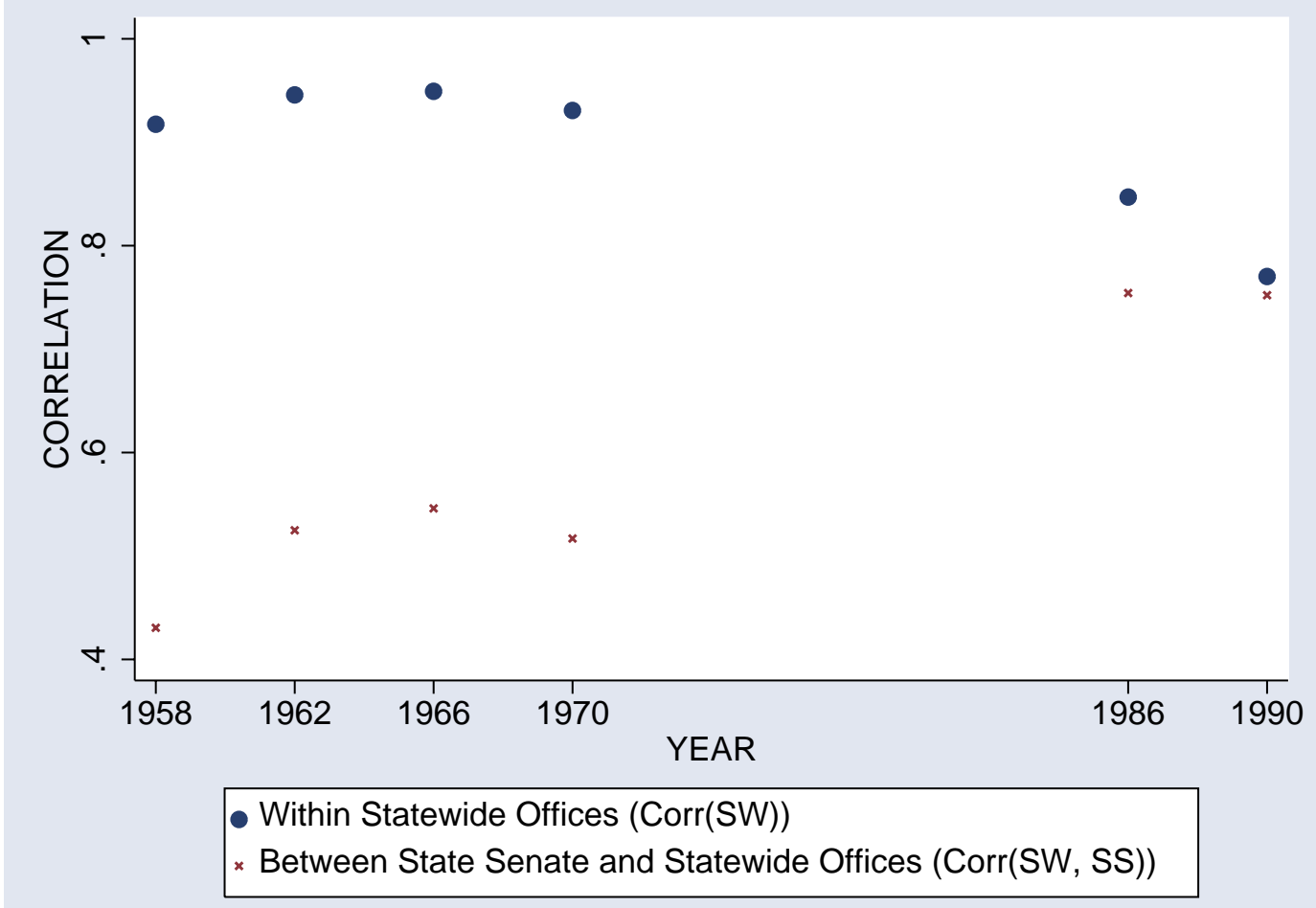

